\title{
Chronic disease in childhood and adolescence: continuity of care in the Health Care Network*
}

\author{
Doença crônica na infância e adolescência: continuidade \\ do cuidado na Rede de Atenção à Saúde \\ Enfermedad crónica en la infancia y adolescencia: continuidad \\ del cuidado en la red de atención sanitaria
}

\author{
Vanessa Medeiros da Nóbrega ${ }^{1}$, Maria Elizabete de Amorim Silva ${ }^{1}$, Leiliane Teixeira Bento Fernandes ${ }^{1}$, Claudia Silveira \\ Viera $^{2}$, Altamira Pereira da Silva Reichert ${ }^{1}$, Neusa Collet ${ }^{1}$
}

How to cite this article:

Nóbrega VM, Silva MEA, Fernandes LTB, Viera CS, Reichert APS, Collet N. Chronic disease in childhood and adolescence: continuity of care in the Health Care Network. Rev Esc Enferm USP. 2017;51:e03226. DOI: http://dx.doi.org/10.1590/S1980-220X2016042503226

* Extracted from the dissertation

"Longitudinalidade e continuidade do cuidado à criança/adolescente com doença crônica e sua família nos servicos de saúde", Universidade Federal da Paraíba, 2014

${ }^{1}$ Universidade Federal da Paraíba, João Pessoa, PB, Brazil.

${ }^{2}$ Universidade Estadual do Oeste do Paraná, Cascavel, PR, Brazil.

\begin{abstract}
Objective: To evaluate the continuity of care for children and adolescents with chronic diseases in the health care network. Methods: This qualitative study was conducted between February and October 2013 with 12 families, six health managers, and 14 health professionals from different health care services in a municipality of the state of Paraiba, Brazil, using focal groups, semi-structured interviews, and medical record consultation. The data were analyzed by triangulation and thematic analysis. Results: Two categories were created: "health care management" and "(dis)continuity of care."We found gaps in the system, including poor data recording aimed to facilitate follow-up and guide the planning actions as well as sporadic and discoordinate services with a limited flow of information, which hinders follow-up over time. Conclusion: Continuity of care in the health care network is limited and creates the need to develop strategies to improve these services.
\end{abstract}

\section{DESCRIPTORS}

Child Health; Adolescent Health; Chronic Disease; Continuity of Patient Care; Health Care; Pediatric Nursing. 


\section{INTRODUCTION}

The population of children and adolescents with chronic diseases has increased worldwide. In the United States, approximately $14 \%$ of the population has a chronic disease, and $9.6 \%$ has two or more chronic diseases ${ }^{(1)}$. In Brazil, a study ${ }^{(2)}$ showed similar results, in which $9.1 \%$ of children aged 0 to 5 years, $9.7 \%$ of children aged 6 to 13 years, and $11 \%$ of adolescents aged 14 to 19 years have chronic diseases. Twelve chronic problems were investigated. However, the areas of hematology, mental health, psychiatry, and developmental disorders were not included and could increase this percentage and the significance of these data for public health in Brazil.

Chronic diseases include several chronic conditions, with a long or indefinite duration, a typically uncertain prognosis, and periods of remission and exacerbation of symptoms over time, and these diseases demand continuous care without necessarily resulting in healing( ${ }^{(3)}$.

In Brazil, the Health Care Network of People with Chronic Diseases, redefined by Ordinance No.483/14 of the Ministry of Health (MH), aims to address the need for continuous care for this population, advocating comprehensive care in all network regions, with the implementation of actions and services aimed at health promotion and protection, disease prevention, diagnosis, treatment, rehabilitation, harm reduction, and health maintenance ${ }^{(4)}$. Although this Ordinance intends to cover the entire life cycle, actions targeted specifically at children and adolescents with chronic diseases are not covered. The specificities of this population create a significant gap in national public policies and expose this group to greater vulnerability because the health care services are not prepared to effectively care for chronic health conditions in this population, which affects the continuity of care.

Continuity of care is an aspect of care experienced over time by individuals who use health care services and is determined by the integration ability of these services to coordinate health care actions coherently ${ }^{(5)}$. In this context, the Family Health Strategy (FHS) aims to reorganize Primary Health Care (PHC) and coordinate care ${ }^{(6)}$ to ensure its continuity from the perspective of longitudinality. However, it has not adequately addressed the demands of children and adolescents with chronic illness and their families, resulting in dissatisfaction and disregard of that service as a trusted source of care $^{(7)}$.

Studies ${ }^{(6,8)}$ indicate that limitations in the continuity of care include gaps in the system of reference and counter reference and the limited coordination of Unified Health System (Sistema Único de Saúde - SUS) as a whole because of the inefficient communication between services and network professionals. Moreover, in the Brazilian states, there is limited access and an unequal distribution of skilled services for the care of children with chronic diseases ${ }^{(9)}$, which causes the permanent migration of families within the Health Care Network (HCN), often leading to an unsuccessful search for care ${ }^{(10)}$.

Therefore, these limitations create the need to reflect on the activities of the HCN and the specificities of care for children and adolescents with chronic diseases, who need an integrated and qualified $\mathrm{HCN}$ to meet their unique health needs.

In this context, this study aims to evaluate the continuity of care for children and adolescents with chronic diseases in the HCN.

\section{METHOD}

The development and analysis of this qualitative study were based on official documents of the $\mathrm{MH}$ on the Health Care Network of People with Chronic Diseases. The participants included 12 family members of children and adolescents with chronic diseases, 14 health professionals, and six health managers from a municipality in the state of Paraíba, Brazil, totaling 32 participants.

The data were collected between February and October 2013. In the first phase of the study, the parents or legal guardians of children and adolescents with chronic diseases were identified in a referral hospital for these diseases. This decision was made because a study ${ }^{(7)}$ indicated the distancing of these users from FHS services. The criteria for inclusion of family members were: being the parents or legal guardians of children and adolescents with chronic diseases and being older than 18 years of age. The parents or legal guardians of children and adolescents diagnosed for less than one year were excluded because this period is believed to be the time that is necessary to experience care in the network.

The techniques used with the family members were Focal Groups (FGs) and individual interviews. Two FGs were created with five and four participants each, and three individual semi-structured interviews were performed, the main question of which was "Which of the $\mathrm{HCN}$ services were sought by the family, and what did each service accomplish to help the family in the care of children?".

The participants residing in the study municipality were invited to participate in the second phase of the study. This phase involved the consultation of hospital and FHS records to assess the care provided to children and adolescents and referrals, the transcription of the content of the records to a Field Diary (FD), and individual interviews with the FHS professionals responsible for the assistance to the families residing in the study municipality. One family member refused to participate in this phase because she preferred to maintain the confidentiality of the diagnosis of the disease of the child.

Individual semi-structured interviews were also conducted with health professionals in the study hospital and managers who served as supporters of the five health districts and coordinators of the Municipal Health Department (MHD) in their workplace. The main question asked to the health professionals was "How is the provision of care to children and adolescents with chronic illness and family members in the health service where you work?"; and the question asked to managers was "What is your perception of the health care provided to children and adolescents with chronic diseases in this municipality?". All individual interviews, with an average duration of 40 minutes, and FGs, with an average duration of 100 minutes, were recorded with the consent of the participants. 
The inclusion criteria for health professionals were: being a nurse or physician from the health services in question or being a Community Health Agent of the family health units designated to each family and having been working as a health professional for at least six months. For managers, the inclusion criteria were: having been working with child and adolescent care in the study municipality and working as a chief professional for at least six months. A single researcher collected the data and used the criteria of sufficiency for the termination of data collection when it was decided that the collected material allowed an adequate assessment of the study sample ${ }^{(11)}$.

The empirical material was subjected to thematic interpretation with data triangulation using three steps: pre-analysis, including a thorough reading of the set of interviews and observations recorded in the FD for a first classification; coding and construction of themes and categories; and final analysis and interpretation of the results ${ }^{(12)}$. It was not possible to include reports from all respondents because of the limited space for the preparation of the article. However, all participants were included in the analysis and contributed to the construction of knowledge about the continuity of care for the study population.

The study complied with the guidelines of Resolution No. 466/12 $2^{(13)}$ of the National Health Council and was approved under Protocol No. 184.351 and Certificate for Ethics Assessment (Certificado de Apresentação para Apreciação Ética - CAAE) No. 11444412.8.0000.5183. All participants signed an informed consent form, and their anonymity was guaranteed by using codes, i.e., Family (F), Professional (P), and Manager (M), followed by the sequential numbering of the interview. The group interviews with family members contained two numbers: the first, placed before the letter, referred to the group number, and the second, placed after the letter, referred to the family member (e.g., 1F1). The hospital services noted during the interviews were also identified by letters (A, B, and $C)$.

\section{RESULTS}

Two empirical categories were created: "Management of health care services provided to children and adolescents with chronic diseases", which addressed the respondents' perceptions of the organization of the care network for care management; and "(Dis)continuity of care for children and adolescents with chronic diseases", which presented the inconsistencies in the $\mathrm{HCN}$ that limited the continuity of care and the implications for the health of these children and adolescents.

\section{Management of the health CARE SERVICES PROVIDED TO CHILDREN AND ADOLESCENTS WITH CHRONIC DISEASES}

The planning of actions in the study municipality was based on the programs and policies established by the $\mathrm{MH}$ and considering that the care for these families has not been adequately addressed:

(...) in the Health Department, there are work groups, and each group has a line of care (...) We meet every two weeks to discuss policies and how to develop them in the municipality (...) I do not see any policy that particularly targets children with chronic diseases (G2).

The subject area is still focused on programs that the Ministry of Health recommends for the FHS (...). I believe that the care for children and adolescents with chronic illness is still weak (G3).

(...) I feel that care for children and closer monitoring of these children still have some limitations. (...) We could identify these children with chronic diseases in child care. (...) However, child care was not a quality indicator and thus was not regarded as a priority among the actions to be developed (G6).

The care provided by the HCN is not organized for the sharing of responsibilities, and a hierarchical organization is still maintained:

I think the flow of the health network is still limited and not adequately structured for care (for children and adolescents with chronicillness). So, weneed tostructure the network and distinguish the low-complexity services from high-complexity services (P1).

The fragile network limits care in the monitoring and management of chronic diseases:

There are no activities intended to dehospitalize chronic patients. The patient is discharged, and we know that in less than one month, the patient will return to the hospital in worse condition, decompensated. There is no network out there structured to provide the necessary care (P1).

Considering these gaps, the managers indicated the need for professionals to promote changes in their working process to change this scenario:

(...) We need to understand the policies and the chronic diseases, but it is necessary to have outreach strategies (...) health care teams need to be aware of the responsibilities of the SUS. (...) The unit's staff cannot simply complete forms (G1).

These gaps in the organization of the $\mathrm{HCN}$ interfere with the continuity of care and are perceived by the families that request changes:

The authorities are not aware that these children really exist, that they need care $(2 \mathrm{~F} 2)$.

\section{(DIS)CONTINUITY OF CARE FOR CHILDREN AND ADOLESCENTS WITH CHRONIC DISEASE}

The HCN has not been effective in everyday actions, particularly with regard to ensuring the continuity of care for children and adolescents with chronic illnesses.

There seems to be no communication between the network services (P3).

In fact, I do not know whether in the FHS the children are monitored or the service simply refers them to us (hospital $A$ ), and nothing else is done (P2).

No health professional monitors her in my city (2F4).

No surveys of children and adolescents with chronic diseases have been performed here in the District (G4).

The consultation of hospital and FHS records allowed the identification of some obstacles to the continuity of 
information, including the disorganization of data records, incomplete and illegible records, and records without proper identification of the chief professional.

Moreover, the hospital records contained repetitive and incomplete data, limited to the recording of the execution of the activities of the health team.

The consultation of FHS records allowed the confirmation of the interview data of the families regarding the limited coordination between the services and staff, demonstrated by the lack of records of health professionals, the absence of child care follow-up records and scarce records on the use of services, and the limitation of the records to cases of exacerbated signs and symptoms of diseases that required antibiotic therapy but without monitoring the outcomes. Of the five records consulted in the FHS, only one supported clinical care, with information on the care provided and monitoring of drug therapy in the FHS.

However, the sharing of information in the $\mathrm{HCN}$ between professionals and services was deficient:

The services that provide care to my child never communicate. I have to take the initiative to say what happened, what medication my child took, and what treatments failed. I take the responsibility to talk about the condition (F1).

We did not contact the new care unit because the service is provided according to the neighborhood and street. The FHS professionals of the new unit never requested information about the child (P14).

The limited communication and coordination of $\mathrm{HCN}$ services hinder its functioning:

This network does not seem to work well; it works through favors and depends on our personal influence, networking, and pleas (P6).

The care network is coordinated among the physicians, and this improves the process. Some treatments are obtained via personal influence (P5).

The limited access to HCN services and the absence of reference and counter reference negatively affect the health of children and adolescents with chronic diseases and their families:

Moving between hospitals was difficult. I was in hospital $B$ to replace the probe; the team did not assist me; then, they asked me to go to hospital $C$, and hospital $C$ sent me back to hospital $B$. From 3 p.m. until almost midnight, my child was not fed and had seizures because he was not taking the medication and had no assistance $(2 \mathrm{~F} 1)$.

The difficulties in monitoring children and adolescents with chronic diseases are related to the lack of feedback from the medical specialties when the children are sent for consultation (P11).

There is a lack of accountability from the team for the development of Singular Therapeutic Projects coordinated with the other levels of care:

Unfortunately, we do not have FHS services that address these cases; these cases are analyzed by specialists, and for the renewal of prescriptions, I need to make a transcript (P12).
The FHP (Family Health Program) doctor who knows my diffculties should try to be more interested in informing himself how to handle this disease because I do not see this effort in the service that I was assigned to. Rather than going to the FHS and being referred to hospitalization, I come straight to the hospital (F3).

The FHS professionals attempt to justify this lack of attitude:

The number of FHS users who need curative care is large, and the Ministry of Health proposes many attributes to FHS professionals, which prevent greater dedication to children and adolescents with chronic diseases (P10).

Another obstacle to the continuity of care is pharmaceutical care:

The medication is expensive; it comes regularly, but the supply may be interrupted, and we do not know when the supply will be restored (P13).

\section{DISCUSSION}

The organization of the $\mathrm{HCN}$ should promote comprehensive care for children and adolescents with chronic diseases, with adequate access to the services for their individual needs and the needs inherent to the chronic condition. From this perspective, the $\mathrm{HCNs}$ were created to reorganize the health care system, considering the needs of the population ${ }^{(3)}$ to ensure that care.

However, action planning has been focused on programs and policies developed by the $\mathrm{MH}$, and therefore, it has the same limitations as Brazilian policies regarding chronic diseases care, such as Ordinance No. 483/2014 ${ }^{(4)}$, for the planning of strategies focused on the care of children and adolescents with chronic diseases. Therefore, these children and adolescents remain invisible to the management programs and, consequently, to health professionals and services. This situation is worrisome because, in everyday life, FHS teams focus on the actions executed by managers, which prevents the implementation of situation analysis and strategic planning that consider the unique needs of health care users.

In Italy, health care is free and universal, and it is funded by the government. $\mathrm{PHC}$ is provided by family pediatricians paid by funds and is responsible for ensuring the coordination and continuity of care between health services and professionals; however, it has limitations ${ }^{(5)}$. These limitations notwithstanding, the system in Italy is better than that in Brazil when one considers improvements such as the development of the SpeNK project to meet the unique needs of children aged less than 16 years with complex or chronic health conditions and special health care needs. The SpeNK project presents the hospital discharge procedures and integrated clinical procedures for child follow-up and guidelines to evaluate the continuity of attention by the family and the role of the family pediatrician ${ }^{(5)}$.

In Brazil, the care actions for children with chronic conditions do not differ from program actions established by the MHD for other assisted children ${ }^{(6)}$. Therefore, our results indicate that health professionals do not address the individual needs of this population and that they are 
unproductive and wait for requests from the management team to implement actions for the affected population.

This reality is known as program vulnerability. This limitation is due to lapses in the attitudes of the professionals who are responsible for the construction, implementation, and evaluation of policies and programs that guide the daily practice of health care ${ }^{(9)}$.

These gaps affect the actions of the care services provided to this population because poor management jeopardizes the organization and quality of care $^{(9)}$. The alienation in the work process of the FHS, in which management proposes the actions and standardized approaches that should be implemented in daily life, makes professionals perform actions without thinking and without considering local conditions ${ }^{(14)}$, and automatized they tend not to be interested in health promotion and knowledge about the needs of the population under their responsibility ${ }^{(15)}$. In this case, the planned actions are limited to child care and do not address the complexity and uniqueness of this population.

The program vulnerability results in uncoordinated interventions, which in isolation cannot produce substantial changes in the health of populations ${ }^{(9)}$ such as children and adolescents with chronic diseases.

In addition, the conception of health professionals toward the work process leads to the provision of sporadic and poor services ${ }^{(16)}$. This fragmented and disjointed management of health care at the program and local levels is unable to meet the care needs of this group of patients and their families because they require continuous care, and this type of care involves the accountability, acceptance, and commitment of the professionals responsible for the planning of direct and indirect actions. Moreover, this population demands a care system that meets its health needs in the different stages of the disease.

Historically, in Brazil, health care has focused on the care of acute conditions, and this work organization strategy persists to date. However, this fragmented work organization in health services is designed to operate reactively, resulting in significant gaps in the care of chronic conditions ${ }^{(3)}$.

Hierarchical organizations also need to be overcome to ensure the adequate functioning of services in polyarchic HCNs, to disrupt vertical work relations, and to enable the provision of continuous and comprehensive care to populations in all health care segments, coordinated by the $\mathrm{FHS}^{(17)}$.

A health care program works comprehensively in cases in which health planning is integrated because all participating services need to have the same level of efficiency to ensure quality of care ${ }^{(18)}$. Each service needs to ensure patient acceptance and accountability of the professionals for the families of children with chronic conditions, seeking to offer individual care for the proper management of the disease.

However, in Brazil, the services available in many municipalities cannot adequately treat chronic diseases, and families are often assisted by professionals without the necessary competence to promote childcare and without knowledge of the disease ${ }^{(9)}$. Therefore, the children are referred to various medical specialties, increasing the costs of the care system, eroding the family's trust, causing frustration, and worsening the non-solved health problems ${ }^{(19)}$.

The training of health professionals to care for this special population of patients and their families and implementing strategies to ensure coordination and communication between network services are critical actions to improve care.

The limitations of the HCN need to be acknowledged and addressed to achieve care that is capable of meeting the needs of this population of patients and their families.

Another limitation of the $\mathrm{HCN}$ is informational continuity because in cases in which there is no integration between the various health services, the necessary flow of information is compromised by the $\mathrm{HCN}$.

This lack of communication between health services and professionals limits the coordination of care by the FHS and the continuity of care by the $\mathrm{HCN}^{(3)}$. A study ${ }^{(8)}$ shows that this gap in communication occurs during hospital discharge because the hospital does not come into contact with the FHS for sharing information to ensure the fundamental conditions for the continuity of care.

In this context, the family starts to play a primary role to compensate for gaps in the continuity of care management and serves as a link between professionals and health institutions to ensure care for the child ${ }^{(5)}$. This limited flow of information in the HCN hinders a broader understanding of the cases because the family tends to summarize the information according to their focus ${ }^{(19)}$ and may unintentionally conceal valuable information. Moreover, when the family is not aware and educated about the child's condition to disclose this information, the lack of attitude of the FHS in establishing communication and information sharing may strongly impair the continuity of care.

This flow of information is hindered within the service because the records of professionals from the hospital and basic health care units contain little information that promotes the continuity of care internally. The lack or precariousness of the medical records jeopardizes qualified follow-up and prevents communication for the planning, continuity, and evaluation of care ${ }^{(6)}$. Nevertheless, clinical data should feed the HCN to facilitate monitoring, evaluate clinical outcomes, and ensure the implementation of the best strategies to improve care ${ }^{(20)}$.

Considering that the physical records are still handwritten, there is inconsistency and disorganization of information, which may discourage health professionals from consulting the medical history of children and adolescents, the records of the implemented therapies, and the outcomes obtained with the treatment to promote continuity of care.

The analysis of the FHS records confirmed the findings of the interviews with health professionals on the fragility of communication in the HCN because these professionals did not have the necessary knowledge about the children and adolescents with chronic diseases and their families to foster proactive and direct care.

The lack of patient acceptance exacerbates the vulnerability and suffering of these families because it creates insecurity and doubts concerning their competence in care ${ }^{(10)}$. The establishment of flow and counter flow in HCN prepares 
the services for users, facilitates access to care, ensures the continuity of care ${ }^{(21)}$, and contributes to the families' sense of satisfaction and security by acknowledging the timely solution of their claims and preventing physical and emotional stress due to the constant search for care services.

FHS professionals should be more engaged to support these families to seek solutions for their care needs because the FHS is physically closer to the users and has the responsibility of knowing the needs of their users for the planning and execution of appropriate actions.

In this process, the FHS is responsible for the coordination of care and is supported by specialist care and the support network for diagnostic, therapeutic, and pharmaceutical care $^{(3)}$. The responsibility for the coordination of care of children and adolescents with chronic diseases may improve access to care services and $\mathrm{HCN}$ actions because this network can quickly mobilize the resources of the medical team and support team to expedite the resolution of chronic cases $^{(10)}$.

In fact, considering the demands of the affected population, the FHS has not taken full responsibility for its actions because upon identifying that these requests are being addressed by a reference service, it declines the responsibility to implement a Singular Therapeutic Project and to coordinate these plans with other levels of care.

The FHS should make efforts in a broader context of health care in the community to coordinate the system for the care of the affected group ${ }^{(22)}$. This perspective strengthens the $\mathrm{HCN}$ by developing a proactive and direct approach and reducing the demands in other levels of care ${ }^{(21)}$.

However, the FHS teams feel overwhelmed by the demand for care in cases of acute conditions because these cases exceed the number of professionals and go beyond the action planning, which is based on the singularities of each population $^{(6)}$. Although this is the reality of many municipalities, children and adolescents with chronic diseases need this support in the coordination of care.

There is an urgent need for changes in the work processes developed by the FHS related to the implementation of supported self-care, in which the affected children/ adolescents and their families actively participate in health care $^{(17)}$. Care that is supported and shared ensures the development of expanded partnerships with a focus on problem-solving.

PHC should gradually increase efforts to implement strategies aiming to change the micro-policies of health care units to promote coordination between health professionals, teams, and services ${ }^{(6)}$, which is essential for overcoming the fragility of the regulatory system responsible for ensuring access to care services. The regulatory system of the $\mathrm{HCN}$ does not respond effectively to the demands of the population, generating significant absenteeism ${ }^{(21)}$ and long waiting periods for consultations. This situation occurs in cases in which the network disregards the users' choice of geographical area for consultations with specialists and examinations because these regions are often distant from their homes, limiting access to services. The inefficiency of the regulatory system is also evident in cases in which the hospital staff uses personal influence to obtain access to services and to expedite examinations and specialized consultations.

The limited access to medicines and supplies is another obstacle to the continuity of care. Most children and adolescents with chronic diseases depend on medicines to maintain a stable clinical condition, and the bureaucracy of the $\mathrm{HCN}$ and the limited supplies are obstacles to continuous care. These families are often low-income and cannot purchase the necessary drugs, which may result in decompensation of the clinical condition of these individuals and the need for hospitalization, affecting the emotional state of the patients and families and increasing costs for the system as a whole.

Considering this reality, the limitations in the continuity of care to these children/adolescents and their families in the HCN make this population even more vulnerable. There is no simple solution for the creation of an efficient and effective health care system for chronic conditions ${ }^{(20)}$. Successful experiences indicate the need for the coordination of all health sectors to support care and build the necessary bridges with community services to overcome the possible practice gaps and to provide continuity of care ${ }^{(22)}$. Therefore, each municipality is responsible for assembling the professionals involved, including nurses, to plan the best strategies for overcoming the obstacles in the network.

It is noticed that the care for this population is limited by the management and planning of public policies and program actions capable of coordinating the $\mathrm{HCN}$. These children/adolescents will remain invisible to the health system as long as managers are not aware of the importance of paying attention to this population.

Much effort is needed to improve the HCN to offer continuous care for children and adolescents with chronic illness and their families. Although the development of this study, considering a single variable, may be a limitation, this study contributes to the construction of knowledge by revealing the gaps in the care for this population, which few studies have evaluated.

\section{CONCLUSION}

Limitations in the continuity of care may contribute to the constant changes in the clinical condition of children and adolescents with chronic diseases and may lead to unnecessary hospitalizations. The fragmented and sporadic care offered to date is unable to meet the demands of this population.

The provision of sporadic care, the lack of coordination between care services, and the limited flow of information indicate the need for in-depth studies on the communication system of the HCN and the harmonization of care services to assess the weaknesses and identify the best strategies to improve this network.

Children and adolescents with chronic diseases have unique needs in each stage of the disease and need to be accepted by HCN members and professionals, including nurses, through care that is supported, extended, continuous, proactive, and direct, which are the essential aspects of care for this population. 
RESUMO

Objetivo: Analisar a continuidade do cuidado à criança/adolescente com doença crônica na rede de atenção à saúde. Método: Pesquisa qualitativa realizada entre fevereiro e outubro de 2013 com 12 familiares, seis gestores e 14 profissionais de saúde de diferentes serviços da rede de saúde de um município da Paraíba através das técnicas de grupo focal, entrevista semiestruturada e consulta a prontuários. A triangulação dos dados e a análise temática subsidiaram a interpretação dos dados. Resultados: Foram construídas duas categorias: "Gestão da atenção à saúde" e "(Des)continuidade do cuidado". Constataram-se lacunas como a ausência de cadastro para favorecer o acompanhamento e nortear o planejamento de ações; atendimento pontual e desarticulado entre os serviços com fragilidade no fluxo de informações, que obstaculizam o seguimento ao longo do tempo. Conclusão: A continuidade do cuidado na rede de atenção à saúde está fragilizada e há necessidade do desenvolvimento de estratégias que a favoreçam.

\section{DESCRITORES}

Saúde da Criança; Saúde do Adolescente; Doença Crônica; Continuidade da Assistência ao Paciente; Atenção à Saúde; Enfermagem Pediátrica.

\section{RESUMEN}

Objetivo: Enfermedad crónica en la infancia y adolescencia: continuidad del cuidado en la red de atención sanitaria. Método: Investigación cualitativa realizada entre febrero y octubre de 2013 con 12 familiares, seis gestores y 14 profesionales sanitarios de distintos servicios de la red sanitaria de un municipio de Paraíba mediante las técnicas de grupo focal, entrevista semiestructurada y consulta a fichas. La triangulación de los datos y el análisis temático subsidiaron la interpretación de los datos. Resultados: Fueron construidas dos categorías: "Gestión de la atención sanitaria" y "(Des)continuidad del cuidado". Se advirtieron lagunas como la ausencia de registro para favorecer el seguimiento y orientar la planificación de acciones; atención puntual y desarticulada entre los servicios con fragilidad en el flujo de informaciones, que obstaculizan el seguimiento a lo largo del tiempo. Conclusión: La continuidad del cuidado en la red de atención sanitaria está fragilizada y existe la necesidad del desarrollo de estrategias que la favorezcan.

\section{DESCRIPTORES}

Salud del Niño; Salud del Adolescente; Enfermedad Crónica; Continuidad de la Atención al Paciente; Atención a la Salud; Enfermería Pediátrica.

\section{REFERENCES}

1. National Survey of Children's Health. Child and Adolescent Health Measurement Initiative (CAHMI), "2011-2012 NSCH: Child Health Indicator and Subgroups SAS Codebook, Version 1.0" 2013 [Internet]. Maryland; 2013 [cited 2016 Feb 02]. Available from: http:// childhealthdata.org/docs/nsch-docs/sas-codebook_-2011-2012-nsch-v1_05-10-13.pdf

2. Instituto Brasileiro de Geografia e Estatística. Pesquisa Nacional por Amostra de Domicílios: um panorama da saúde no Brasil, acesso e utilização dos serviços, condições de saúde e fatores de risco e proteção à saúde, 2008. Rio de Janeiro: IBGE; 2010.

3. Brasil. Ministério da Saúde, Secretaria de Atenção à Saúde. Documento de diretrizes para o cuidado das pessoas com doenças crônicas nas Redes de Atenção à Saúde e nas linhas de cuidado prioritárias. Brasília: MS; 2013.

4. Brasil. Ministério da Saúde. Portaria n. 483, de 01 de abril de 2014. Redefine a Rede de Atenção à Saúde das Pessoas com Doenças Crônicas no âmbito do Sistema Único de Saúde (SUS) e estabelece diretrizes para a organização das suas linhas de cuidado. Diário Oficial da União, Brasília, 02 abr. 2014. Seção 1, p. 50.

5. Zanello E, Calugi S, Rucci P, Pieri G, Vandini S, Faldella G, et al. Continuity of care in children with special healthcare needs: a qualitative study of family's perspectives. Ital J Pediatr. 2015;41:7.

6. Duarte ED, Silva KL, Tavares TS, Nishimoto CLJ, Silva PM, Sena RR. Care of children with a chronic condition in primary care: challenges to the healthcare model. Texto Contexto Enferm. 2015;24(4):1009-17.

7. Neves ET, Silveira A, Arrué AM, Pieszak GM, Zamberlan KC, Santos RP. Rede de cuidados de crianças com necessidades especiais de saúde. Texto Contexto Enferm. 2015;24(2):399-406.

8. Coelho APC, Larocca LM, Chaves MMN, Felix JVC, Bernadino E, Alessi SM. Healthcare management of tuberculosis: integrating a teaching hospital into Primary Health Care. Texto Contexto Enferm. 2016;25(2):e0970015.

9. Pedroso MLR, Motta MGC. Children and family living with chronic conditions: mesosystem in connection with program vulnerability. Texto Contexto Enferm. 2013;22(2):493-9.

10. Costa EAO, Dupas G, Sousa EFR, Wernet M. Children's chronic disease: family needs and their relationship with the Family Health Strategy. Rev Gaúcha Enferm. 2013;34(3):72-8.

11. Minayo MCS, Assis SG, Souza ER. Avaliação por triangulação de métodos: abordagem de programas sociais. Rio de Janeiro: FIOCRUZ; 2014.

12. Minayo MCS. O desafio do conhecimento: pesquisa qualitativa em saúde. São Paulo: Hucitec; 2014.

13. Brasil. Conselho Nacional de Saúde. Resolução n. 466, de 12 de dezembro de 2012. Dispõe sobre diretrizes e normas regulamentadoras de pesquisas envolvendo seres humanos [Internet]. Brasília; 2012 [citado 2016 jul.08]. Disponível em: http://conselho.saude.gov.br/ resolucoes/2012/Reso466.pdf

14. Cardoso JR, Oliveira GN, Furlan PG. Gestão democrática e práticas de apoio institucional na Atenção Primária à Saúde no Distrito Federal, Brasil. Cad Saúde Pública. 2016;32(3):e00009315.

15. Flisch TMP, Alves RH, Almeida AC, Torres HC, Schall VT, Reis DC. Como os profissionais da atenção primária percebem e desenvolvem a Educação Popular em Saúde? Interface (Botucatu) 2014; 18 Supl 2:1255-68. 
16. Rehem T. Silva A, Vasconcelos A, Ciosak S, Egry E. Internações por Condições Sensíveis à Atenção Primária: percepção de usuários e profissionais de saúde. Atas CIAIQ [Internet] 2016 [citado 2016 jul 08];2:1039-48. Disponível em: http://proceedings.ciaiq.org/index. php/ciaiq2016/article/view/852/838.

17. Mendes EV. A construção social da Atenção Primária à Saúde. Brasília: Conselho Nacional de Secretários de Saúde; 2015.

18. Rucci P, Latour J, Zanello E, Calugi S, Vandini S, Faldella G, et al. Measuring parents' perspective on continuity of care in children with special health care needs. Int J Integr Care [Internet] 2015 [cited 2016 June 28];15:e046. Available from: https://www.ncbi.nIm.nih.gov/ pmc/articles/PMC4843181/

19. Lister G. 2011 Joseph W. St Geme Jr lecture: five things I'd like to see changed in american pediatrics, five lessons I've learned. Pediatrics. 2012;129(5):961-7.

20. Lima RAG. Chronic conditions and the challenges for knowledge production in health [editorial]. Rev Latino Am Enfermagem. 2013;21(5):1011-2.

21. Erdmann AL, Andrade SR, Mello ALSF, Drago LC. Secondary Health Care: best practices in the health services network. Rev Latino Am Enfermagem 2013;21(n.spe):131-9.

22. Rosenthal MP. Childhood asthma: considerations for primary care practice and chronic disease management in the village of care. Prim Care. 2012;39(2):381-91.

Financial support:

Conselho Nacional de Desenvolvimento Científico e Tecnológico (CNPq). Process nº 474762/2013-0. 